\title{
Assessment of the energy efficiency of a public university building in Southern Brazil
}

\begin{abstract}
The adequate assessment of the thermal performance of a building requires the knowledge of its characteristics within its inserted context, making it possible to verify the actual and future performance of the building. Therefore, this study aims to analyse the energy efficiency of a public university building located in southern Brazil. The assessment was carried out according to the Brazilian Technical Regulation for Energy Efficiency Labelling of Commercial, Services and Public Buildings (RTQ-C). In this study, the building envelopment was evaluated under the actual condition and in the reference condition, using the simplified method. The constructive parameters of the building were obtained from the architectural project and technical standards, although the assigned climatic group of the building was defined based on the Brazilian bioclimatic zones. In the end, it was possible to identify the energetic efficiency level of the envelopment through the total annual thermal load of the building in its actual condition. Considering the urban and climatic context, as well as constructive characteristics of the building, strategies were proposed that can be adopted even in the project planning stage, aiming to improve the classification of the envelopment and to meet the energy efficiency policies of the country.
\end{abstract}

\section{Introduction}

Sustainability has been increasingly a greater challenge for the public sector and it is directly related to the issue of energetic efficiency. Besides using efficient technologies and conservation of natural resources, public policies are necessary to reroute technological choices, as well as investments in the sector [1].

In the opinion of Manfron et al. [2], sustainability in civil construction means to "dedicate greater attention on physical, environmental, energetic, and technological resources of our planet and issues related to the efficiency of constructive processes in such a way as to bring about the least possible impact on the environment and individuals".

According to Lamberts et al. [3], energy efficiency can be understood as the potential of a building to provide thermal, visual, and acoustic comfort to its users, yet with low energy consumption. Therefore, a building is more energetically efficient than another one when it provides the same environmental conditions, but with lower energy consumption.

Regarding this, buildings must consider ways to avoid excessive electric energy consumption. Hence, the rational use of energy must be based on conservation and the efficient usage of natural resources, reducing wastage, and impacts on the environment [4].

The National Energy Conservation and Efficiency Policy (2010-2030) was drafted to deal with these issues, which envisions diverse initiatives on long-term planning, among which, the incentive for energetic efficiency in public buildings [5].

\subsection{Energetic efficiency programs in public buildings in Brazil}

The Electric Energy Conservation Program - PROCEL, was created in 1997 and it was exclusively focused on public buildings for the purpose of promoting energetic efficiency initiatives in this type of building. The following are some of the purposes of this program: reduce the consumption of electric energy in public buildings and the demand for energy in the country; as well as improve working and comfort conditions of civil servants [6].

"Procel Edifíca" and the "Programa Brasileiro de Etiquetagem" (Brazilian Labeling Program) were other energetic efficiency programs in buildings created by INMETRO (the Brazilian standardization entity) and ELETROBRAS [7].

Besides that, the performance standard of the "Associação Brasileira de Normas Técnicas" (Brazilian National Standards Organization) is an important tool for determining the minimum requisites, parameters, and evaluation methods of thermal performance in buildings [8].

RTQ-C is the Technical Quality Regulation for Commercial, Service, and Public Buildings that makes it possible to determine the energetic efficiency level of the building ranging from $\mathrm{A}$ to $\mathrm{E}$, based on the thermal and energetic performance [9]. According to Melo et al. [10], Level A ranking in the Brazilian regulation is equivalent to the reference model proposed by ANSI/ASHRAE Standard 90.1-2007.

RTQ-C is divided into three parts: lighting, climate control (air-conditioning/heating), and envelopment; there are two evaluation methods (prescriptive and 
simulation). In the prescriptive method, the overall classification is derived from an equation that is attributed to a weighted value for each evaluated requisite. Yet, in the simulation method, it is performed using the aid of a computer program [11].

It should be emphasized that energy consumption is increasing, arising from human activities, equipment usage, and service providing in public organizations, as well as in private. It is possible to adopt solutions for the purpose of reducing energy consumption and costs during their operating phase in public buildings, such as making the correct choice of building materials, adequate climate control building project planning, and the use of the most efficient equipment [12].

The purpose of this article based on what has been expressed, is to analyse the energetic efficiency of the envelopment of a public building used for higher education located in Joinville, in southern Brazil, employing the RTQ-C regulations.

\section{Methods}

\subsection{The purpose of the study}

The Technological Science Centre building at the "Universidade do Estado de Santa Catarina" (Santa Catarina State University) (UDESC), a public university building, was analysed, as shown in Figure 1. The building is located in Joinville/SC and there are $4,674.71 \mathrm{~m}^{2}$ of constructed area, as it is a 5-story building: the ground floor, 3 intermediate floors, and the top floor, as showed in Figure 2.

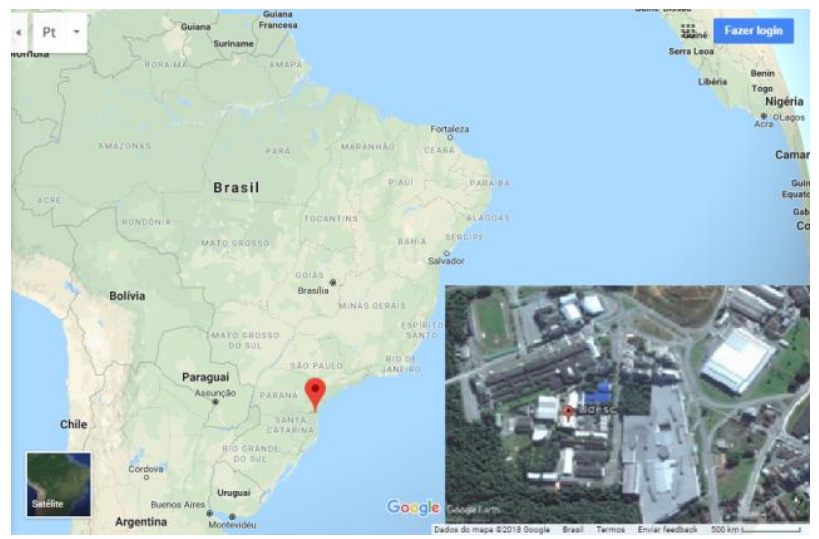

Fig. 1. Location of the analysed building.

The analysed environments include laboratories, classrooms, and a meeting room on the ground floor, as well as the first floor; the library is on the second floor; a mezzanine with study rooms on the fourth floor; and an auditorium on the top floor of the building.

It is important to stress that the analysed building is still in the construction phase. The walls of this building are made from ceramic bricks and plaster coated, and the roof is made from sandwich-type tiles. The building will be covered by white, straw-coloured, red, and green wall tiles, in adherence to the UDESC standard colour scheme.
The window glass of the building will be smooth, $6 \mathrm{~mm}$ thickness, and coated with bronze-coloured film.
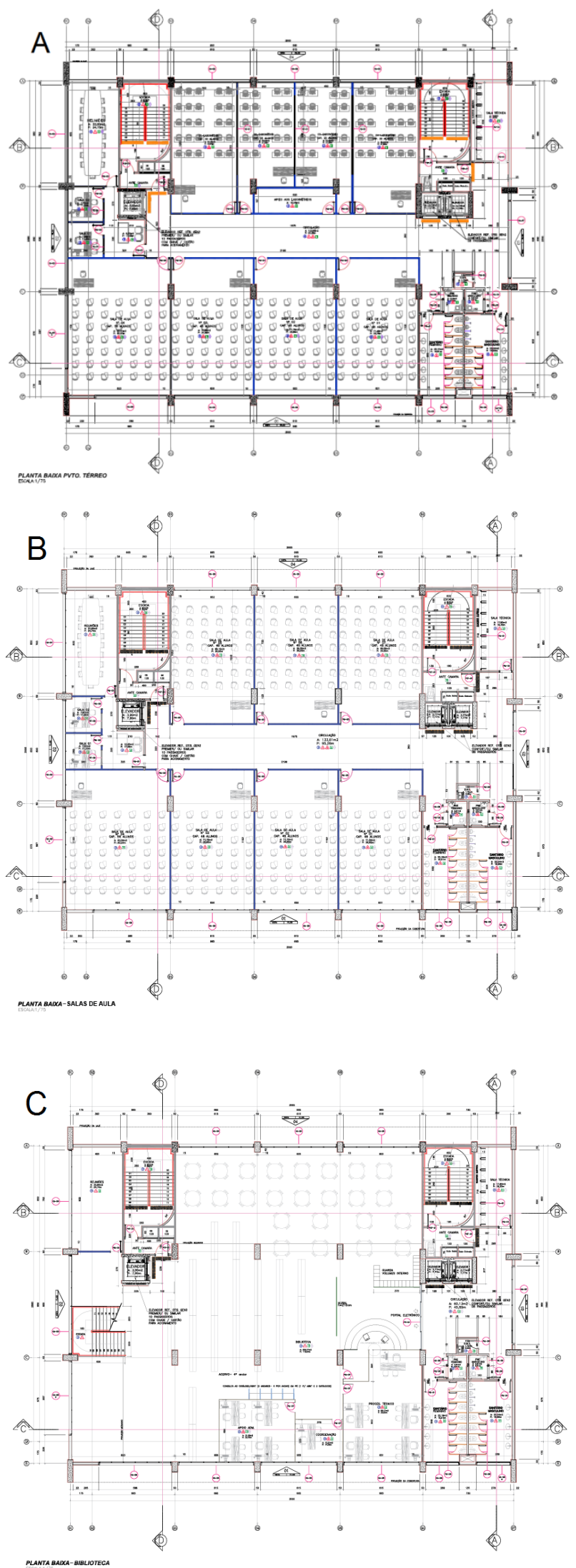

Fig. 2. Floor plan: (A) ground floor; (B) $1^{\text {st }}$ floor; (C) $2^{\text {nd }}$ floor; 

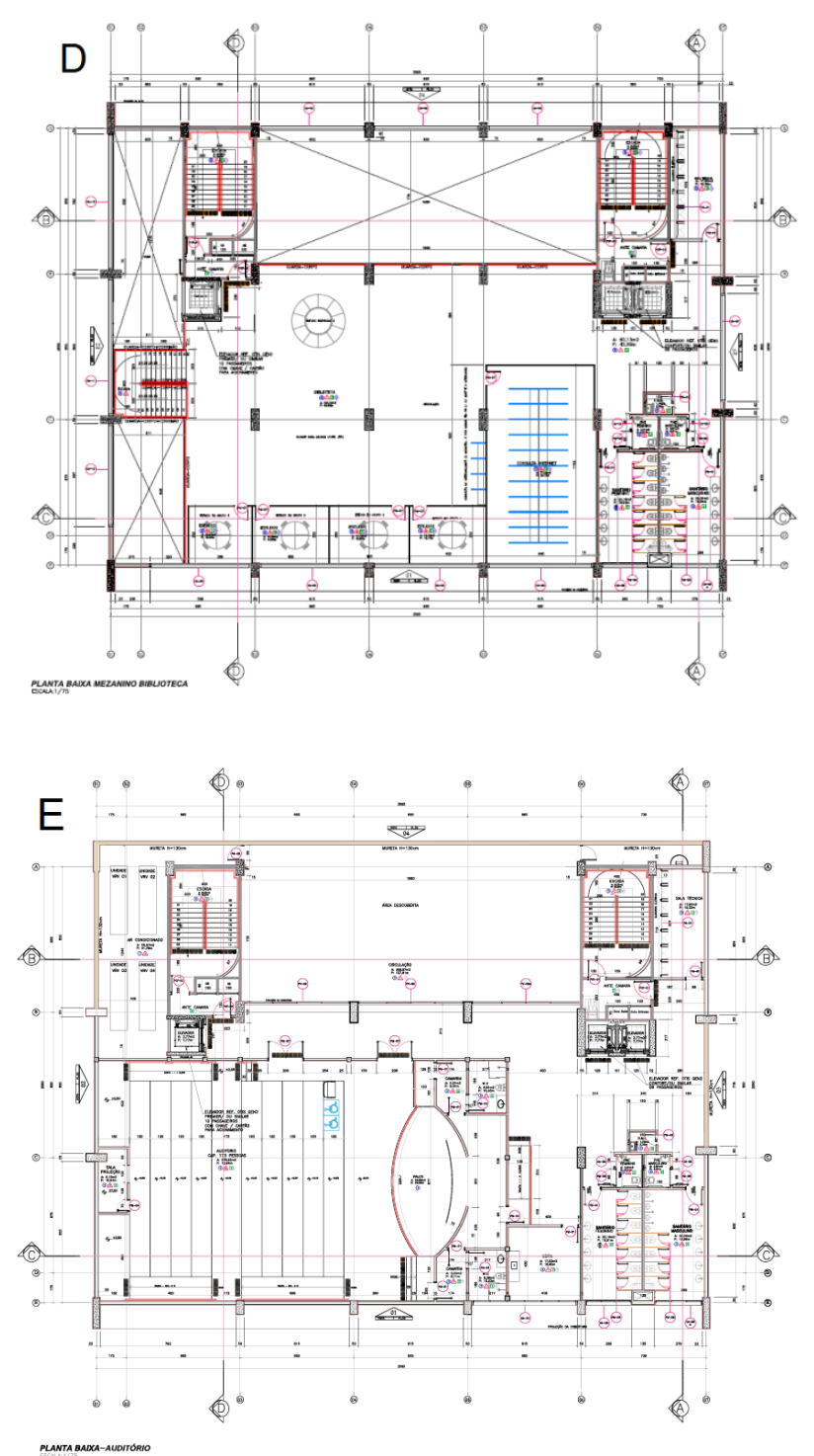

Fig. 2. Continuation: (D) $3^{\text {rd }}$ floor; (E) top floor.

\subsection{Energetic efficiency assessment of the envelopment}

The energetic efficiency assessment of the envelopment was performed by employing the simplified RTQ-C method in this study, considering the artificially climate controlled environments. The application of the simplified method is justified, since the constructive parameters of the building were understood between the application intervals of the method, as described in Table 1.

The envelopment of the building was analysed under the actual condition and the reference condition (corresponding to class D). Predefined reference parameters were considered in this case for the educational typology of higher education, as shown in Table 2.

Thus, the thermal performance of the envelopment was defined based on the total annual thermal load of the building in its actual and reference conditions. The total annual thermal load, in turn, was obtained by utilizing the
Web Interface from the simplified method, considering the physical, geometric, and internal load parameters of the building.

Table 1. Building parameters limits adhered with by the simplified method

\begin{tabular}{|c|c|c|}
\hline Parameters & $\begin{array}{l}\text { Minimum } \\
\text { Value }\end{array}$ & $\begin{array}{l}\text { Maximum } \\
\text { Value }\end{array}$ \\
\hline $\begin{array}{l}\text { Solar absorptance of the roof } \\
(\alpha)\end{array}$ & 0.2 & 0.8 \\
\hline $\begin{array}{l}\text { Solar absorptance from the } \\
\text { wall }(\alpha)\end{array}$ & 0.2 & 0.8 \\
\hline $\begin{array}{l}\text { Adjacent obstruction angle } \\
\text { (AOV) }\end{array}$ & $0^{\circ}$ & $80^{\circ}$ \\
\hline $\begin{array}{l}\text { Horizontal shadowing angle } \\
\text { (AHS) }\end{array}$ & $0^{\circ}$ & $80^{\circ}$ \\
\hline $\begin{array}{l}\text { Vertical shadowing angle } \\
\text { (AVS) }\end{array}$ & $0^{\circ}$ & $90^{\circ}$ \\
\hline $\begin{array}{l}\text { Roof thermal capacity } \\
\text { (CTcob) }\end{array}$ & $0.22 \mathrm{~kJ} / \mathrm{m}^{2} \mathrm{~K}$ & $450 \mathrm{~kJ} / \mathrm{m}^{2} \mathrm{~K}$ \\
\hline $\begin{array}{l}\text { Wall thermal capacity } \\
\text { (CTpar) }\end{array}$ & $0.22 \mathrm{~kJ} / \mathrm{m}^{2} \mathrm{~K}$ & $450 \mathrm{~kJ} / \mathrm{m}^{2} \mathrm{~K}$ \\
\hline Ground contact & No contact & In contact \\
\hline $\begin{array}{l}\text { Equipment power density } \\
\text { (DPE) }\end{array}$ & $4 \mathrm{~W} / \mathrm{m}^{2}$ & $40 \mathrm{~W} / \mathrm{m}^{2}$ \\
\hline Lighting power density (DPI) & $4 \mathrm{~W} / \mathrm{m}^{2}$ & $40 \mathrm{~W} / \mathrm{m}^{2}$ \\
\hline Solar glass factor $(\mathrm{FS})$ & 0.21 & 0.87 \\
\hline Zenithal opening percentage & $0 \%$ & $3 \%$ \\
\hline Ceiling height $(\mathrm{CH})$ & $2.6 \mathrm{~m}$ & $6.6 \mathrm{~m}$ \\
\hline $\begin{array}{l}\text { Façade opening percentage } \\
\text { (PFO) }\end{array}$ & $0 \%$ & $80 \%$ \\
\hline Insulated floor & $\begin{array}{c}\text { No, if } \\
\text { insulated } \\
<5 \mathrm{~mm}\end{array}$ & $\begin{array}{c}\text { Yes, if } \\
\text { insulated } \\
>5 \mathrm{~mm}\end{array}$ \\
\hline $\begin{array}{l}\text { Roof thermal transmittance } \\
\text { (Ucob) }\end{array}$ & $0.51 \mathrm{~W} / \mathrm{m}^{2} \mathrm{~K}$ & $\begin{array}{c}5.07 \\
\mathrm{~W} / \mathrm{m}^{2} \mathrm{~K} \\
\end{array}$ \\
\hline $\begin{array}{l}\text { External wall thermal } \\
\text { transmittance (Upar) }\end{array}$ & $0.50 \mathrm{~W} / \mathrm{m}^{2} \mathrm{~K}$ & $\begin{array}{c}4.40 \\
\mathrm{~W} / \mathrm{m}^{2} \mathrm{~K}\end{array}$ \\
\hline $\begin{array}{l}\text { Glass thermal transmittance } \\
\text { (Uvid) }\end{array}$ & $1.9 \mathrm{~W} / \mathrm{m}^{2}$ & $5.7 \mathrm{~W} / \mathrm{m}^{2}$ \\
\hline
\end{tabular}

Firstly, the analysed environments were divided into perimeter and internal thermal zones, according to the building architectural project, based on the calculations of the respective areas in each zone. After that, input parameters were defined for the Web Interface, regarding the thermal properties and specific parameters were obtained from the building architectonic project, Brazilian technical standards, and other pertinent documents.

The building location (state and city) characteristics were inserted in the Web Interface, the total number of floors, typology, and number of thermal zones in each floor. It is important to emphasize that the available Web Interface options only included the cities of Florianópolis and Urubici, considering the state of Santa Catarina.

Although the building is located in Joinville, however, the city of Florianópolis was defined for calculating the thermal load. Since, for the sequence of items from the new RTQ-C prescriptive method, the characteristics of the city of Joinville were used. 
Table 2. Reference parameters of the walls and roof in educational buildings.

\begin{tabular}{|c|c|c|c|c|}
\hline \multirow[b]{3}{*}{ Typical usage } & \multicolumn{4}{|c|}{ Educational buildings } \\
\hline & \multirow[b]{2}{*}{$\begin{array}{c}\text { Actual } \\
\text { condition }\end{array}$} & \multicolumn{3}{|c|}{ Reference condition } \\
\hline & & $\begin{array}{c}\text { Primary } \\
\text { education }\end{array}$ & $\begin{array}{c}\text { Elementary and } \\
\text { middle school } \\
\text { education }\end{array}$ & $\begin{array}{c}\text { Higher } \\
\text { education }\end{array}$ \\
\hline \multicolumn{5}{|l|}{ Geometry } \\
\hline Shape & \multicolumn{4}{|c|}{ Actual condition } \\
\hline Solar Orientation $\left({ }^{\circ}\right)$ & \multicolumn{4}{|c|}{ Actual condition } \\
\hline Ceiling height (floor to ceiling) $(\mathrm{m})$ & \multicolumn{4}{|c|}{ Actual condition } \\
\hline \multicolumn{5}{|l|}{ Openings } \\
\hline PAF -Façade opening percentage (\%) & $\begin{array}{c}\text { Actual } \\
\text { condition }\end{array}$ & \multicolumn{3}{|c|}{40} \\
\hline PAZ - Zenithal opening percentage (\%) & $\begin{array}{c}\text { Actual } \\
\text { condition }\end{array}$ & \multicolumn{3}{|c|}{0} \\
\hline \multicolumn{5}{|l|}{ Constructive Components } \\
\hline Wall & $\begin{array}{c}\text { Actual } \\
\text { condition }\end{array}$ & \multicolumn{3}{|c|}{$\begin{array}{l}\text { Internal plastering }(2.5 \mathrm{~cm}) \text {, core-hole ceramic blocks } \\
(9 \mathrm{~cm}) \text {, external plastering }(2.5 \mathrm{~cm})\end{array}$} \\
\hline Upar - External wall transmittance $\left(\mathrm{W} / \mathrm{m}^{2} \mathrm{~K}\right)$ & $\begin{array}{c}\text { Actual } \\
\text { condition }\end{array}$ & \multicolumn{3}{|c|}{ (2) } \\
\hline$\alpha \mathrm{PAR}$ - Wall absorptance (dimensionless) & $\begin{array}{c}\text { Actual } \\
\text { condition }\end{array}$ & \multicolumn{3}{|c|}{0.5} \\
\hline CTpar - Wall thermal capacity $\left(\mathrm{kJ} / \mathrm{m}^{2} \mathrm{~K}\right)$ & $\begin{array}{c}\text { Actual } \\
\text { condition }\end{array}$ & \multicolumn{3}{|c|}{150} \\
\hline Roof & $\begin{array}{c}\text { Actual } \\
\text { condition }\end{array}$ & \multicolumn{3}{|c|}{$\begin{array}{l}\text { Fibre cement mesh, Air layer chamber }(>5 \mathrm{~cm}) \text { and solid } \\
\text { concrete slab }(10 \mathrm{~cm})\end{array}$} \\
\hline Ucob - Roof transmittance $\left(\mathrm{W} / \mathrm{m}^{2} \mathrm{~K}\right)$ & $\begin{array}{l}\text { Actual } \\
\text { condition }\end{array}$ & \multicolumn{3}{|c|}{ 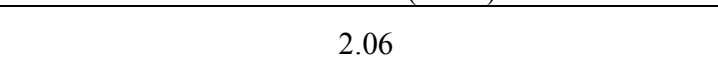 } \\
\hline aCOB - Roof absorption (dimensionless) & $\begin{array}{c}\text { Actual } \\
\text { condition }\end{array}$ & \multicolumn{3}{|c|}{0.8} \\
\hline CTcob - Roof thermal capacity $\left(\mathrm{kJ} / \mathrm{m}^{2} \mathrm{~K}\right)$ & $\begin{array}{c}\text { Actual } \\
\text { condition }\end{array}$ & \multicolumn{3}{|c|}{233} \\
\hline Glass & $\begin{array}{c}\text { Actual } \\
\text { condition }\end{array}$ & \multicolumn{3}{|c|}{ Single colourless glass $6 \mathrm{~mm}$} \\
\hline FS - Glass solar factor (dimensionless) & $\begin{array}{c}\text { Actual } \\
\text { condition }\end{array}$ & \multicolumn{3}{|c|}{0.82} \\
\hline Uvid - Glass transmittance $\left(\mathrm{W} / \mathrm{m}^{2} \mathrm{~K}\right)$ & $\begin{array}{l}\text { Actual } \\
\text { condition }\end{array}$ & \multicolumn{3}{|c|}{5.7} \\
\hline AHS - Horizontal shadowing angle $\left({ }^{\circ}\right)$ & $\begin{array}{c}\text { Actual } \\
\text { condition }\end{array}$ & \multicolumn{3}{|c|}{0} \\
\hline AVS - Vertical shadowing angle $\left({ }^{\circ}\right)$ & $\begin{array}{c}\text { Actual } \\
\text { condition }\end{array}$ & \multicolumn{3}{|c|}{0} \\
\hline AOV - Vertical obstruction angle $\left({ }^{\circ}\right)^{*}$ & $\begin{array}{c}\text { Actual } \\
\text { condition }\end{array}$ & \multicolumn{3}{|c|}{ Actual condition } \\
\hline \multicolumn{5}{|l|}{ Lighting and reduction } \\
\hline DPI - Lighting power density $\left(\mathrm{W} / \mathrm{m}^{2}\right)^{* *}$ & $\begin{array}{c}\text { Actual } \\
\text { condition }\end{array}$ & \multicolumn{3}{|c|}{$15,5^{* * *}$} \\
\hline Occupation ( $\mathrm{m}^{2} /$ person $)$ & $\begin{array}{l}\text { Reference } \\
\text { condition }\end{array}$ & 2.5 & 1.5 & 1.5 \\
\hline DPE - Equipment power density $\left(\mathrm{W} / \mathrm{m}^{2}\right)$ & $\begin{array}{l}\text { Reference } \\
\text { condition }\end{array}$ & 15.0 & 9.7 & 9.7 \\
\hline Occupancy time (hours) & \multicolumn{4}{|c|}{8} \\
\hline Occupancy days $\left(\mathrm{N}_{\mathrm{ano}}\right)^{* * * *}$ & \multicolumn{4}{|c|}{200} \\
\hline Floor condition & & Ac & ndition & \\
\hline Roof condition & & & ndition & \\
\hline Floor insulation & $\begin{array}{c}\text { Actual } \\
\text { condition }\end{array}$ & & No insulation & \\
\hline
\end{tabular}

Furthermore, the constructive elements for each thermal zone were informed, such as absorptance, transmittance, and thermal capability. solar orientation; façade opening percentage; glass solar factor; lighting power density; and occupancy hours; ground contact; as well as the dimension of the ceiling height. The thermal properties of the walls and roof are displayed in Figure 3 and Figure 4, respectively. 
After concluding the input of the actual parameters of the building in the Web Interface, the annual thermal load was obtained in $\mathrm{kWh}$. Afterwards, the same procedure was performed considering the reference values (Table 2). Thus, the total annual thermal load of the building was obtained in the actual condition ( $\left.\mathrm{CgT}_{\mathrm{TACTUAL}}\right)$ and reference $\left(\mathrm{CgT}_{\mathrm{TREF}}\right)$.

\begin{tabular}{|c|c|c|c|}
\hline Wall & Description & $\begin{array}{c}\mathbf{U} \\
\left(\mathbf{W} / \mathbf{m}^{2} . \mathbf{K}\right)\end{array}$ & $\begin{array}{c}\mathbf{C T} \\
\left(\mathbf{k J} / \mathbf{m}^{2} \cdot \mathbf{K}\right)\end{array}$ \\
\hline & $\begin{array}{l}\text { The walls are made from } 8 \text { - } \\
\text { circular hole bricks, laid in the } \\
\text { larger dimension. } \\
\text { Brick dimensions: } \\
\text { 10.0X20.0X20.0cm. } \\
\text { Brick-laying mortar thickness: } \\
1.0 \mathrm{~cm} \\
\text { Roughcast plastic thickness: } \\
2.5 \mathrm{~cm} \\
\text { Wall thickness: } 25.00 \mathrm{~cm}\end{array}$ & 1,61 & 232 \\
\hline
\end{tabular}

Fig. 3. Wall thermal properties.

\begin{tabular}{|c|c|}
\hline 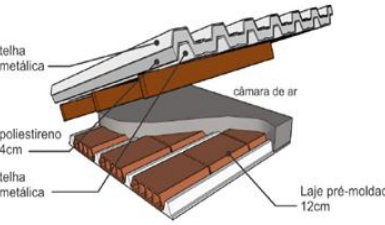 & $\begin{array}{l}\text { Precast concrete slab ceramic } \\
\text { bricks } 12 \mathrm{~cm}(\text { concrete } 4 \mathrm{~cm}+ \\
\text { EPS } 7 \mathrm{~cm}+\text { mortar } 1 \mathrm{~cm}) \\
\text { Air chamber }(>5.0 \mathrm{~cm}) \\
\text { Metallic tile } * 0.1 \mathrm{~cm} \\
\text { Polystyrene } 4.0 \mathrm{~cm} \\
\text { Metallic tile } * 0.1 \mathrm{~cm}\end{array}$ \\
\hline \multicolumn{2}{|c|}{$\begin{array}{l}\text { * The thermal transmittance does not change no matter if it is a } \\
\text { trapezoidal or corrugated shape }\end{array}$} \\
\hline$\frac{U}{\left[\mathrm{~W} /\left(\mathrm{m}^{2} \mathrm{k}\right)\right]}$ & $\frac{C_{T}}{\left[k \mathrm{k} / \mathrm{m}^{2} \mathrm{~K}\right]}$ \\
\hline 0,65 & 176 \\
\hline
\end{tabular}

Fig. 4. Thermal properties of the roof.

In order to obtain the energetic efficiency classification level of the envelopment, it was also necessary to calculate the form factor (FF) of the building, related to the envelopment area and the total constructed volume, as well as the reduction coefficient of the total annual thermal load from class $\mathrm{D}$ to class $\mathrm{A}\left(\mathrm{CRCT}_{\mathrm{D}-\mathrm{A}}\right)$, defined based on FF, the climatic group of the building is inserted and the analysed typology. Moreover, it calculated the coefficient (i) through Equation 1.

$$
i=\frac{C g T_{T R E F} \cdot C R C T_{D-A}}{3}
$$

Whereas:

$\mathrm{CgT}_{\text {TREF }}$ is the total thermal load of the building in its reference condition $[\mathrm{kWh} /$ year];

$\mathrm{CRCT}_{\mathrm{D}-\mathrm{A}}$ is the coefficient of the annual thermal load reduction from class $\mathrm{D}$ to class $\mathrm{A}$.

Thus, it was possible to prepare a relative scale for the energetic efficiency class of the envelopment of the building, as displayed in Table 3 .

Finally, the total annual thermal load of the building was compared to the scale classification limits for the analysed building, identifying the energetic efficiency class of the envelopment.

\section{Results}

The thermal load results are presented on the envelopment, as well as the energetic efficiency classification of the building.

The total thermal load of the building in the actual and the reference conditions were $\mathrm{CgT}_{\mathrm{TACTUAL}}=400723.46$ $\mathrm{kWh}$ and $\mathrm{CgT}_{\mathrm{TREF}}=411650.69 \mathrm{kWh}$, respectively.

The annual thermal load reduction from class $\mathrm{D}$ to class A $\left(\mathrm{CRCT}_{\mathrm{D}-\mathrm{A}}=0.14\right)$ was obtained based on the building form factor $(\mathrm{FF}=0.17)$ and the climatic group related to the city where the building is located (GCL 9), as shown in Table 4.

Following that, the coefficient $i$ calculated according to Equation 1, and finally, it was possible to obtain the intervals on the energetic efficiency for the analysed building, as shown in Table 5 .

Table 3. Intervals of the energetic efficiency of the envelopment.

\begin{tabular}{|c|c|c|c|c|c|}
\hline $\begin{array}{c}\text { Efficiency } \\
\text { class }\end{array}$ & A & B & C & D & E \\
\hline $\begin{array}{c}\text { Upper } \\
\text { limit }\end{array}$ & - & $>\mathrm{CgT}_{\mathrm{TREF}}-3 i$ & $>\mathrm{CgT}_{\mathrm{TREF}}-2 i$ & $>\mathrm{CgT}_{\mathrm{TREF}}-i$ & $>\mathrm{CgT}_{\mathrm{TREF}}$ \\
\hline $\begin{array}{c}\text { Lower } \\
\text { limit }\end{array}$ & $<\mathrm{CgT}_{\mathrm{TREF}}-3 i$ & $\leq \mathrm{CgT}_{\mathrm{TREF}}-2 i$ & $\leq \mathrm{CgT}_{\mathrm{TREF}}-2 i$ & $\leq \mathrm{CgT}_{\mathrm{TREF}}$ & - \\
\hline
\end{tabular}

Table 4. The coefficient of the total annual thermal load reduced from class D to class A.

\begin{tabular}{|c|c|c|c|c|c|}
\hline \multirow{2}{*}{$\begin{array}{l}\text { Climatic } \\
\text { Group }\end{array}$} & \multicolumn{5}{|c|}{$\begin{array}{l}\text { The coefficient of the total annual thermal load reduced from class D to class A } \\
\left(\text { (CRCT }_{D-A}\right)\end{array}$} \\
\hline & FF $\leq 0.2$ & $0.20<$ FF $<0.30$ & $0.30<$ FF $<0.40$ & $0.40<$ FF $<0.50$ & FF $>0.50$ \\
\hline GCL $1-A$ & 0.19 & 0.19 & 0.22 & 0.25 & 0.27 \\
\hline GCL $1-B$ & 0.14 & 0.15 & 0.17 & 0.18 & 0.19 \\
\hline GCL 2 & \multirow{3}{*}{0.19} & \multirow{3}{*}{0.20} & \multirow{3}{*}{0.26} & \multirow{3}{*}{0.35} & \multirow{3}{*}{0.41} \\
\hline GCL 3 & & & & & \\
\hline GCL 4 & & & & & \\
\hline GCL 5 & \multirow{2}{*}{0.15} & \multirow{2}{*}{0.15} & \multirow{2}{*}{0.17} & \multirow{2}{*}{0.18} & \multirow{2}{*}{0.19} \\
\hline GCL 6 & & & & & \\
\hline GCL 7 & \multirow{2}{*}{0.14} & \multirow{2}{*}{0.15} & \multirow{2}{*}{0.18} & \multirow{2}{*}{0.23} & \multirow{2}{*}{0.27} \\
\hline GCL 8 & & & & & \\
\hline GCL 9 & 0.14 & 0.15 & 0.17 & 0.19 & 0.21 \\
\hline
\end{tabular}


Table 5. The intervals of the energetic efficiency classes from the studied envelopment

\begin{tabular}{|c|c|c|c|c|c|}
\hline $\begin{array}{c}\text { Efficiency } \\
\text { class }\end{array}$ & A & B & C & D & E \\
\hline $\begin{array}{c}\text { Upper } \\
\text { limit }\end{array}$ & - & 354020 & 373230 & 392440 & 411651 \\
\hline $\begin{array}{c}\text { Lower } \\
\text { limit }\end{array}$ & 354020 & 373230 & 392440 & 411651 & - \\
\hline
\end{tabular}

Then, the actual thermal load value was compared from the building to the intervals shown in Table 5. Thus, the envelopment classification of the building was verified as level $\mathrm{D}$, demonstrating low thermal and energetic performance of the analysed building.

The openings are predominately facing north and east, respectively, regarding the constructive factors. This relation between the openings and the orientation of the façades, yet without any constructive measure to mitigate the insolation, directly negatively impacts the energetic efficiency index of the construction.

There is a constructive solution for reducing this opening/insolation relation by using components as solar shading, considered as protection shading elements.

The northern façade gets all the sunlight during the entire day (solar zenith angle), thus horizontal solar shading is recommended, while on the eastern façade, it gets sunlight during the morning period, so vertical solar shading is recommended.

The utilization of vegetation, as a shading element, is also a factor that must be considered during the project planning phase, jointly with regional climatic factors, such as the predominant winds as to contribute in the natural ventilation of the environments.

The usage of reduced solar-factor glass (preferably using a film) is another strategy to be considered for the purpose of maximizing the energetic efficiency of the envelopment. The utilization of reduced solar factor glass (preferably covered by film) for the purpose of decreasing the heat index absorbed and then transmitted to the environment is another strategy to be considered.

The utilization of lighter colours is recommended to obtain an even better classification, as they display greater refraction indexes, while colours such as red and dark green, used on this analysed building façade display higher heat absorption indexes.

The material used on the roofing is another parameter that needs to be considered. Thermal-acoustic sandwich panels were used in this project, which are made from metallic tiles and insulation is between the layers. These are favourable to the building efficiency regarding thermal comfort.

Quevedo et al. [13] analysed the envelopment of a public education building located in Southern Brazil, as described in the RTQ-C prescriptive method. The authors confirmed that the building was classified as energetic level A. Thus; one can perceive that it is possible to obtain the maximum level of energetic efficiency, as long as adequate energetic efficiency measures are adopted, such as the previously mentioned strategies. In this case, it is necessary to consider geometric and constructive parameters of the building, as well as the regional climate.
Regarding the potential energy conservation, it is fitting to emphasize that level A buildings can achieve at least $20 \%$ energy savings compared to level D [14]. Thus, it is extremely important to adopt efficient energetic measures aimed at enhanced thermal-energetic performance and consequently, decreased energy consumption.

\section{Conclusion}

This article presented the obtainment of the thermal load and subsequent classification of the energetic efficiency of a higher education building, located in southern Brazil. Class D envelopment classification was confirmed considering the data collected on the envelopment properties and the constructive characteristics.

This study observed that it is important to consider urban and climatic variables, as they can significantly reduce the energetic consumption in a building, as well as greatly improve the comfort of the users.

Finally, the results obtained from this research study can assist municipal administrators in decision-making regarding projects being executed in the public sector. Thus, it is possible to comply with energetic efficiency policies, and thereby avoid emergency measures for rationing energy, as well as promote savings in public resources and building sustainability.

\section{References}

1. M. Menkes. Eficiência Energética, Políticas Públicas e Sustentabilidade (2004)

2. V. Manfron, G. Mucelli, P. Paganuzzi, N. Sinopoli, V. Tatano. Costruire il Progetto Sostenibile. Set. 2006. Universidade IUAV de Veneza.

3. R. Lamberts, L. Dutra, F.O.R. Pereira. Eficiência energética na arquitetura, 3 (2014)

4. Brasil. Manual de Instruções para Projetos de Eficiência Energética nos Prédios Públicos Utilização dos Recursos da Reserva Global de Reversão (2011)

5. N.N. Batista, E.L.L. Rovere, J.C.R. Aguiar. Energy efficiency labeling of buildings: An assessment of the Brazilian case. Energy and Buildings, 43 (2011)

6. Ministério das Minas e Energia. Plano Nacional de Eficiência Energética: Capítulo 1 (2011)

7. C. Bueno. Avaliação de desempenho ambiental de edificações habitacionais: Análise comparativa dos sistemas de certificação no contexto brasileiro (2010)

8. ABNT, Associação Brasileira de Normas Técnicas. NBR 15220-3:2005 (2005)

9. Brasil. Ministério do Desenvolvimento, Indústria e Comércio Exterior. Portaria INMETRO n 372 (2010)

10. A.P. Melo, M.J. Sorgato, R. Lamberts. Building energy performance assessment: Comparison between ASHRAE standard 90.1 and Brazilian regulation. Energy and Buildings, 70 (2014) 
11. J. Carlo, R. Lamberts. Development of envelope efficiency labels for commercial buildings: Effect of different variables on electricity consumption. Energy and Buildings, 40 (2008)

12. A.C.G. Rocha. Eficientização energética em prédios públicos: um desafio aos gestores municipais frente aos requisitos de governança e sustentabilidade. EAESP - MPGPP (2012)

13. T.C. Quevedo, V.A.R. Baumann, R.S. Versage. Análise paramétrica do nível de eficiência energética da envoltória de uma edificação pública pelo método prescritivo do RTQ-C. X ENLAC - Encontro Latino Americano de Conforto no Ambiente Construído (2017)

14. V.A. Scalco, R.W. Fonseca, E.O. Beck, G.D. Palladini, T. Maia, L. Eli, R. Lamberts. Análise do potencial de economia baseado em edificações comerciais etiquetadas. XV ENTAC - Encontro Brasileiro de Teconologia do Ambiente Construído (2014) 